\title{
RELATIONSHIPS BETWEEN MACROINVERTEBRATE COMMUNITIES AND ENVIRONMENTAL PARAMETERS OF THE HU-LAN ESTUARY NATURAL WETLAND RESERVE AND ITS SURROUNDING WATERS, NORTHEAST CHINA
}

\author{
ShabANi, I. E. ${ }^{1,2,3}-$ LiU, M. H. ${ }^{1 *}-$ YU, H. X. ${ }^{1 *}-$ MuhigWA, J.-B. B. ${ }^{2}-$ KANKONDA, B. A. ${ }^{3}-$ \\ Eкоко, W. A. ${ }^{1,3}-$ CUI, X. B. ${ }^{4}-$ WANG, G. X. ${ }^{4}$ \\ ${ }^{1}$ Laboratory of Hydrobiology, College of Wildife and Protected Area, Northeast Forestry \\ University, Harbin P.O. Box 150040, China \\ ${ }^{2}$ Université Officielle de Bukavu, P.O. Box 570-Bukavu, République Démocratique du Congo \\ ${ }^{3}$ University of Kisangani, P.O. Box 2012 - Kisangani, République Démocratique du Congo \\ ${ }^{4}$ Naoli River National Nature Reserve of Heilongjiang, Shuangyashan P.O. Box 155811, China \\ ${ }^{*}$ Corresponding authors \\ e-mail: manhong@nefu.edu.cn; china.yhx@163.com \\ (Received 22 ${ }^{\text {nd }}$ Apr 2019; accepted $4^{\text {th }}$ Jul 2019)
}

\begin{abstract}
This study analyzed the relationships between environmental parameters and benthic macroinvertebrate faunas. Invertebrate richness, Shannon-Wiener diversity, functional-group and CCA were used to evaluate conditions of waterbodies of the Hu-lan Estuary Natural Wetland Reserve and its hinterlands. We measured 10 physicochemical variables and collected 165 species belonging to 6 functional feeding groups (FFGs) during spring, summer and autumn. Some of the physicochemical factors changed with seasons. Nitrate nitrogen, total nitrogen and total phosphate significantly varied with seasons $(p<0.05)$, unlike water temperature, depth, $\mathrm{pH}$, dissolved oxygen, chemical oxygen demand, Ammonia nitrogen and electronic conductivity $(p>0.05)$. The taxa richness of benthic macroinvertebrates did not vary significantly within the sites $(p=0.508)$; while the Shannon-Wiener diversity showed significantly difference $(p<0.01)$ within the sites over these three seasons. Gatheringcollectors were the most abundant macroinvertebrate FFG assemblages all over the sites, though there's no significant difference in the total abundance of 6 functional feeding groups identified among the sites during spring, summer and autumn ( $p=0.677, p=0.681, p=0.302$, respectively). Our CCA results indicated positive correlations of macroinvertebrate community compositions with environmental variables in the Hu-lan Estuary Natural Wetland Reserve and its surrounding waters.
\end{abstract}

Keywords: taxa richness, Shannon-Wiener diversity, functional feeding groups, water parameters, canonical correspondence analysis

\section{Introduction}

Wetlands suffer from anthropogenic pressure and therefore are altered with respect to their physicochemical composition and species diversity (Rivera-Usme et al., 2015). They are essential for the maintenance of biodiversity that depends on the wetlands for their water supply. These aquatic systems are fragile because of high population densities subsequent to accelerated urban development that seriously threatens most of its wetlands (Rivera-Usme et al., 2015). Anthropogenic activities have severely affected the condition of wetlands worldwide (Wilkins et al., 2015; Tan and Beh, 2016). Physical alteration, habitat loss, water withdrawal, pollution (Cao et al., 1997; Morse et al., 2007), overexploitation and the introduction of exotic species all contribute to the decline in freshwater species and water quality as well (Tan and Beh, 2016). The stream 
community structure is a result of both long-term environmental factors and short-term critical conditions of short duration (Morse et al., 2007); and an experienced stream biologist with good knowledge of normal and stressed stream community structures often can evaluate the water quality of a stream with considerable accuracy just after a few minutes' examination of its fauna (Hilsenhoff, 1977).

Benthic macroinvertebrates are an important component of the aquatic ecosystem and reflect a multitude of physical, chemical, and biological stream features allowing them to be excellent indicators of stream health (Hilsenhoff, 1977; Allan, 2004); i.e, the impacts of stressors such as organic pollution, toxins, and physical habitat alterations or foodweb links at higher trophic levels such as fish and birds (Cummins, 1992). Among members of the aquatic environments, they are probably best suited because they are numerous in almost every stream, and they are readily collected and identified, and they are not very mobile, and generally have life cycles of a year or more (Hilsenhoff, 1977). Monitoring wetland ecosystems using aquatic macroinvertebrates has been an effective tool for documenting changes in community health (Lenat, 1987; Plafkin et al., 1989). Some macroinvertebrate indices of stream health have been identified as most useful and efficacious. These include the EPT taxa richness-Ephemeroptera, Plecoptera, Trichoptera- (Lenat and Penrose, 1996), and total benthic macroinvertebrate taxa richness (Plafkin et al., 1989). The effective use of EPT or taxa richness measures for monitoring water quality in China requires richness rating systems to be developed by biologists (Lenat, 1994). However, physicochemical monitoring tools are usually expensive and can only be used at limited site number and they are, thus, unable to achieve computation of distribution patterns (Swaminathan, 2003). Hence, biological monitoring is considered one of the alternatives which is a useful as a rapid assessment instrument to check up the status of water quality (Tan and Beh, 2016). Changes in benthic macroinvertebrate fauna with water pollution (Morse et al., 2007), have been documented and measured in several instances using various aspects including biomass, density and composition (Cao, 1997).

Benthic macroinvertebrate functional feeding-group analyses were developed initially for streams (Cummins, 1973, 1974) as key components of the river continuum concept (Vannote et al., 1980). Various ratios of the functional groups have been successfully used as surrogates for ecosystem attributes to assess the ecological condition of flowing water environments (Masese et al., 2014; Fu et al., 2016; Shabani et al., 2019). The evaluation is based on easily observed morphological and behavioral attributes associated with feeding (functional-feeding groups, FFGs) and modes of attachment, concealment, and locomotion (functional-habit groups, FHGs), together with life history patterns and drift propensity (Merritt et al., 2002).

In this paper, we determined the functional group composition of benthic macroinvertebrate fauna and modeled relationships between benthic macroinvertebrate metrics and environmental factors in the Hu-lan Estuary Natural Wetland Reserve and its surrounding waters to evaluate the effects of environmental characteristics on benthic macroinvertebrate assemblages.

\section{Materials and methods}

\section{Study area}

The Hu-lan Estuary Natural Wetland Reserve is located in the southern part of $\mathrm{Hu}$ lan district, Harbin city in Heilongjiang Province, Northeast China (Fig. 1); and extends 
along of the north bank of Songhua River from East to West band. The Hu-lan River enters the estuary of Songhua River and reaches the Dadingshan dam. The natural reserve extends between $45^{\circ} 53^{\prime} 44^{\prime \prime}$ and $46^{\circ} 54^{\prime} 04^{\prime \prime} \mathrm{N}$ latitude and between $126^{\circ} 41^{\prime} 00^{\prime \prime}$ and $127^{\circ} 15^{\prime} 00^{\prime \prime}$ E longitude. The length of the reserve from East to West is $63.5 \mathrm{~km}$, with a width of $21.3 \mathrm{~km}$ from North to South (Liu, 2012). It covers around $192.62 \mathrm{~km}^{2}$. The annual temperature average is $3.3^{\circ} \mathrm{C}$, with mean annual precipitations of $500.4 \mathrm{~mm}$ (Liu, 2012). The Hu lan Estuary Natural Wetland Reserve was created in 2008 and mainly aims to protect wetland ecosystems and endangered waterfowls. The wetland is rich in biological resources with more than 465 species of plants and 348 species of vertebrates, including fishes, amphibians, reptiles, birds and mammals (Liu, 2012). According to the Classification Criteria of Nature Reserve Types and Grades of the People's Republic of China (GB/T15629-93), the Hu-lan Estuary Natural Wetland Nature Reserve belongs to the inland wetland type and natural ecosystem category. Ashihe River is an important tributary of Harbin section of Songhua River in Hu-lan Estuary. The upper reaches of Ashihe River are alpine forest streams and the middle reaches of the river pass through a large area of farmland to reach the Harbin city and join the Songhua River (Liu, 2012).

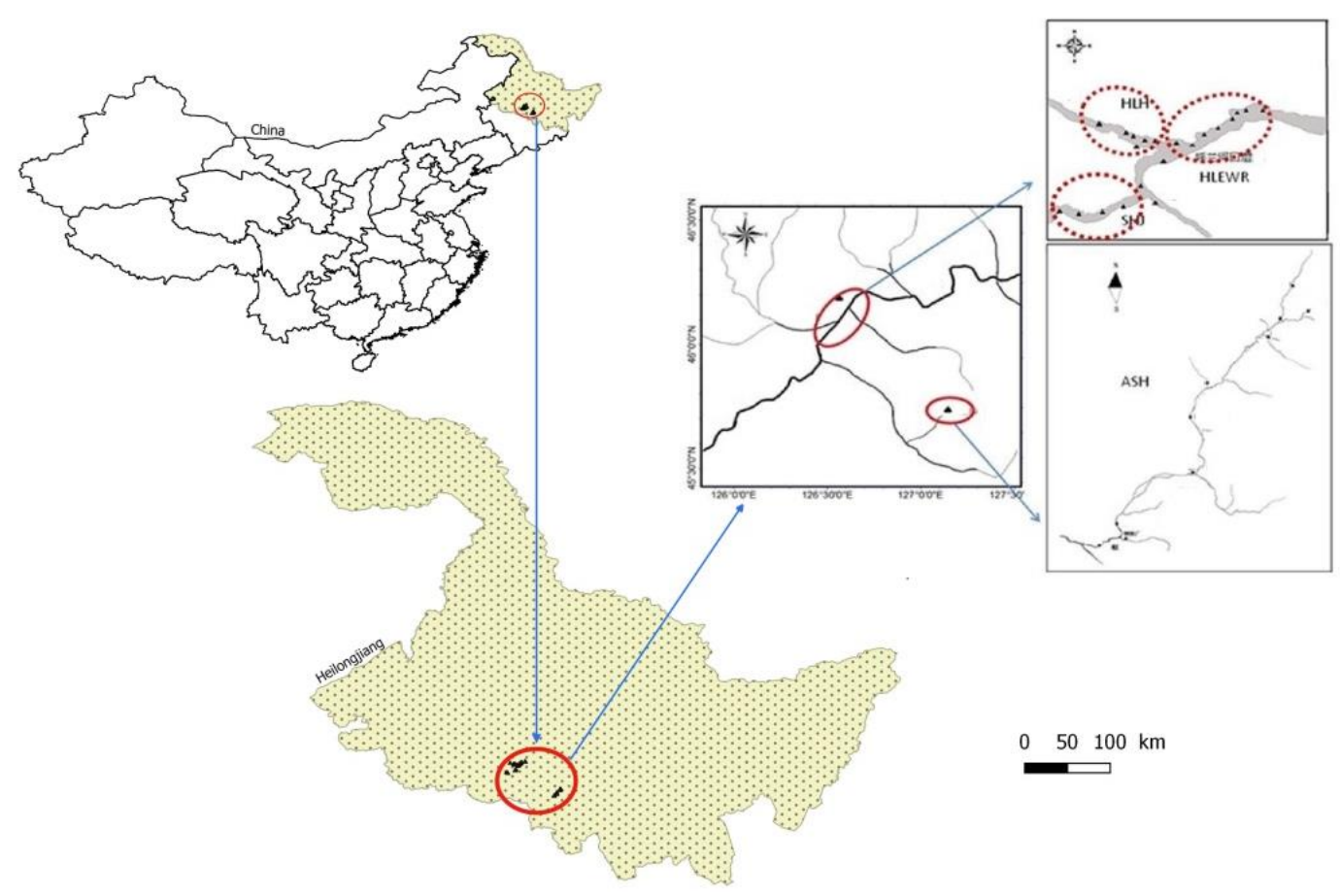

Figure 1. Map of study site with the sampling locations in China

\section{Sampling of physical and chemical parameters}

Four sampling locations were selected, including the Songhua River along Harbin (SHJ: N45 $45^{\prime} 29.2^{\prime \prime}$ and E126 ${ }^{\circ} 5^{\prime} 10.4^{\prime \prime}$, sites 1-3, 13-14), the Ashihe River upstream

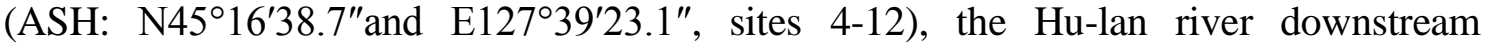
(HLE: N45 $55^{\prime} 33.1^{\prime \prime}$ and E126 $46^{\prime} 35.8^{\prime \prime}$, sites 15-22) and the Hu-lan estuary wetland

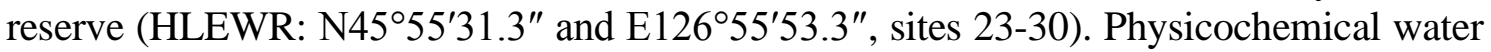
conditions were determined in spring, summer and autumn in 2009. Water temperature 
(WT, $\left.{ }^{\circ} \mathrm{C}\right), \mathrm{pH}$, electronic conductivity $(\mathrm{EC}, \mathrm{mS} / \mathrm{m}$ ) and dissolved oxygen (DO, $\mathrm{mg} / \mathrm{l})$ were measured in situ with a multiparameter probe. Water depth $(\mathrm{m})$ was measured using Secchi disk and longline method when biological samples were collected. $500 \mathrm{ml}$ of water were sampled at each site per season and put in labelled plastic containers, and then taken to the Laboratory of Hydrobiology, where nitrate nitrogen $\left(\mathrm{NO}_{3}{ }^{-}-\mathrm{N}, \mathrm{mg} / \mathrm{l}\right)$, Ammonia nitrogen $\left(\mathrm{NH}_{3}-\mathrm{N}, \mathrm{mg} / \mathrm{l}\right)$, total phosphate $(\mathrm{TP}, \mathrm{mg} / \mathrm{l})$, total nitrogen $(\mathrm{TN}, \mathrm{mg} / \mathrm{l})$ and chemical oxygen demand with permanganate index $\left(\mathrm{COD}_{\mathrm{Mn}}, \mathrm{mg} / \mathrm{l}\right)$ were determined following the Chinese national water quality standards method GB3838-2002.

\section{Benthic macroinvertebrate sampling}

Several qualitative and quantitative sampling tools are designed to sample benthic macroinvertebrates (Barbour et al., 1999; Merritt et al., 2008). In this study, we used qualitative (D-frame net and handle net) and quantitative (Surber sampler: $0.09 \mathrm{~m}^{2}$ and Petersen grab sampler: $1 / 16 \mathrm{~m}^{2}$ ) sampling tools to collect the benthic macroinvertebrates from each of the four sampling locations. We used $500-\mu \mathrm{m}$ mesh Dnet and handle-net type devices at each site, the nets were dragged against the water flow over an area of $1 \mathrm{~m}^{2}$ while large substrates were gently rubbed or kicked for 3-5 minutes with hands or feet, respectively, to dislodge free-living and burrowing macroinvertebrates from benthic substrates. Surber type sampling devices of $30 \mathrm{~cm}$ wide $\times 30 \mathrm{~cm}$ long with $0.09 \mathrm{~m}^{2}$ catching area and a net of $500 \mu \mathrm{m}$ in mesh size were placed along the river substrate to catch any organisms dislodged initially and carried downstream at low velocities; and the animals were subsequently swept by the water and caught in the net. We also used the Petersen sampler in wetland sites to collect macroscopic macroinvertebrates in sand, gravel, marl, or clay.

All samples were transferred into labelled plastic bags and preserved in $95 \%$ ethanol. Taxonomic determinations were conducted in the Laboratory of Hydrobiology using identification keys of Thorp and Covich (1991), Morse et al. (1994), Merritt et al. (1996), Tong (1996), and Dudgeon (1999). Each taxon was assigned to a general functional group according to their trophic specializations, as categorized by Cummins and Klug (1979), Morse et al. (1994), Vannote et al. (1980), Merritt et al. (1996), and Barbour et al. (1999). The FFGs identified were scrapers (SC), that are herbivores and feed on periphyton; shredders $(\mathrm{SH})$, that feed on coarse particulate organic matter (CPOM); gatherers/collectors (GC), that consume fine particulate organic matter (FPOM); filterers/collector (FC), which filter FPOM in the water column; omnivores $(\mathrm{OM})$, or those which simply do not fit neatly into the other categories; and predators (PR) that feed on other living organisms (Rivera-Usme et al., 2015).

\section{Data analysis}

The benthic macroinvertebrate taxa richness and Shannon-Wiener diversity were computed for each site and sampling season using PAST software (Hammer et al., 2001; Hammer and Ryan, 2008). Differences in benthic macroinvertebrate taxa richness and Shannon-Wiener diversity among sampling sites during spring, summer and autumn were tested using the ANOVA or Kruskal-Wallis tests in R software, and tests were considered significant at the $p<0.05$ level. Canonical correspondence analysis was performed using CANOCO 4.5 software and Pearson correlation test (SPSS, version 16.0) to model on the correlation between benthic macroinvertebrate metrics and environmental factors. For data which fitted to the normal distribution, one-way 
ANOVA and Tukey's honestly significant difference (HSD) tests, followed by Levene's test of homogeneity of variance were performed for multiple comparisons. On the other hand, data which did not fit to the normal distribution were submitted to the nonparametric Kruskal-Wallis test to evaluate the relationships between water quality variables and macroinvertebrate community metrics among sites over three seasons.

\section{Results and discussion}

\section{Environmental variables}

Table 1 shows the mean values of ten water parameters measured in the Hu-lan estuary wetland sites and its surrounding waters. Some of the physicochemical factors changed among seasons. Nitrate nitrogen $\left(\mathrm{NO}_{3}{ }^{-}-\mathrm{N}\right)$, total nitrogen $(\mathrm{TN})$ and total phosphate (TP) significantly varied with seasons (Kruskal-Wallis test, $p<0.05$ ); unlike water temperature (WT), depth, $\mathrm{pH}$, dissolved oxygen (DO), chemical oxygen demand with permanganate index $\left(\mathrm{COD}_{\mathrm{Mn}}\right)$, Ammonia nitrogen $\left(\mathrm{NH}_{3}-\mathrm{N}\right)$ and electronic conductivity (EC) which did not vary significantly (Kruskal-Wallis test, $p>0.05$ ). Shabani et al. (2019) also found $\mathrm{NO}_{3}{ }^{-}-\mathrm{N}$, TN and TP concentrations significantly varied with seasons in the waterbodies of Sanjiang plain wetlands. Maloney and Feminella (2006) also recorded the highest mean value of water temperature in summer in the Southeastern plains ecoregion of central western Georgia, USA. Ortiz and Puig (2007) also found the highest mean value of water temperature in summer at the downstream reach in a Mediterranean stream. Shabani et al. (2019) also reported the highest mean value of water temperature in summer in the Sanjiang plain wetlands, obviously as the warmest season.

Table 1. Seasonal dynamics of environmental parameters (Mean \pm SE). WT $=$ Water temperature, $D O=$ dissolved oxygen, $C O D_{M n}=$ chemical oxygen demand, $\mathrm{NH}_{3}-\mathrm{N}=$ Ammonia nitrogen, $\mathrm{NO}_{3}{ }^{-}-\mathrm{N}=$ nitrate nitrogen, $E C=$ electronic conductivity, $T N=$ total nitrogen, $T P=$ total phosphate

\begin{tabular}{c|c|c|c}
\hline Environmental parameters & Spring & Summer & Autumn \\
\hline $\mathrm{WT}\left({ }^{\circ} \mathrm{C}\right)$ & $12.95 \pm 0.70^{\mathrm{a}}$ & $21.20 \pm 0.78^{\mathrm{c}}$ & $16.31 \pm 0.96^{\mathrm{b}}$ \\
Depth $(\mathrm{m})$ & $6.24 \pm 1.02^{\mathrm{a}}$ & $6.93 \pm 1.09^{\mathrm{a}}$ & $5.05 \pm 0.85^{\mathrm{a}}$ \\
$\mathrm{pH}$ & $7.39 \pm 0.10^{\mathrm{ab}}$ & $7.31 \pm 0.06^{\mathrm{a}}$ & $7.62 \pm 0.08^{\mathrm{b}}$ \\
$\mathrm{DO}(\mathrm{mg} / \mathrm{l})$ & $7.67 \pm 0.39^{\mathrm{a}}$ & $7.38 \pm 0.31^{\mathrm{a}}$ & $6.29 \pm 0.45^{\mathrm{a}}$ \\
$\left.\mathrm{CODMn}^{\mathrm{a}} \mathrm{mg} / \mathrm{l}\right)$ & $3.32 \pm 0.44^{\mathrm{a}}$ & $8.74 \pm 0.83^{\mathrm{c}}$ & $5.31 \pm 0.28^{\mathrm{b}}$ \\
$\mathrm{NH}_{3}-\mathrm{N}(\mathrm{mg} / \mathrm{l})$ & $0.54 \pm 0.15^{\mathrm{a}}$ & $0.41 \pm 0.15^{\mathrm{a}}$ & $0.57 \pm 0.27^{\mathrm{a}}$ \\
$\mathrm{NO}_{3}{ }^{-}-\mathrm{N}(\mathrm{mg} / \mathrm{l})$ & $0.68 \pm 0.14^{\mathrm{a}}$ & $1.24 \pm 0.12^{\mathrm{a}}$ & $0.75 \pm 0.07^{\mathrm{b}}$ \\
$\mathrm{EC}(\mathrm{mS} / \mathrm{m})$ & $15.73 \pm 1.67^{\mathrm{a}}$ & $17.12 \pm 1.95^{\mathrm{a}}$ & $15.39 \pm 1.94^{\mathrm{a}}$ \\
$\mathrm{TN}(\mathrm{mg} / \mathrm{l})$ & $3.41 \pm 0.27^{\mathrm{b}}$ & $1.80 \pm 0.16^{\mathrm{a}}$ & $1.51 \pm 0.42^{\mathrm{a}}$ \\
$\mathrm{TP}(\mathrm{mg} / \mathrm{l})$ & $0.11 \pm 0.03^{\mathrm{a}}$ & $0.05 \pm 0.002^{\mathrm{a}}$ & $0.30 \pm 0.06^{\mathrm{b}}$ \\
\hline
\end{tabular}

\section{Benthic macroinvertebrate communities}

A total of 165 benthic macroinvertebrate species belonging to 16 orders were recorded during the study period (Appendix 1, Table 2). Insects were the most speciesrich group, with 8 orders (Trichoptera, Ephemeroptera, Plecoptera, Diptera, Heteroptera, Odonata, Coleoptera and Neuroptera), and $41.8 \%$ of the species belonged to order of Dipterans (Table 2). Limnodrilus hoffmeisteri (Tubificida) was considerably abundant in the Hu-lan estuary wetland and the surrounding Waters. 78 species were 
collected in the Hu-lan river downstream (HLE) followed by the Ashihe River upstream (ASH) with 71 species, the Songhua River along Harbin (SHJ) with 59 species and the Hu-lan estuary wetland reserves (HLEWR) with 52 species (Appendix 1). The benthic macroinvertebrate taxa richness of in these four regions did not vary significantly during the three seasons (ANOVA results, $p=0.5081$; Fig. 2a). While the ShannonWiener diversity showed high significant difference (Kruskal-Wallis test, $p=0.0019$, Fig. 2b) within the sampling zones during these three seasons.

Table 2. Orders and number of families and species of benthic macroinvertebrates

\begin{tabular}{c|c|c|c|c}
\hline Order & Family number & $\mathbf{\%}$ & Species number & $\mathbf{\%}$ \\
\hline Arhynchobdellida & 1 & 2.63 & 2 & 1.21 \\
Coleoptera & 1 & 2.63 & 2 & 1.21 \\
Decapoda & 1 & 2.63 & 2 & 1.21 \\
Diptera & 5 & 13.2 & 69 & 41.80 \\
Ephemeroptera & 6 & 15.80 & 13 & 7.88 \\
Heteroptera & 2 & 5.26 & 6 & 3.64 \\
Heterostropha & 1 & 2.63 & 2 & 1.21 \\
Hygrophila & 2 & 5.26 & 10 & 6.06 \\
Neuroptera & 1 & 2.63 & 1 & 0.61 \\
Odonata & 2 & 5.26 & 2 & 1.21 \\
Plecoptera & 1 & 7.89 & 6 & 3.64 \\
Rhynchobdellida & 8 & 2.63 & 1.82 \\
Trichoptera & 2 & 21.10 & 20 & 12.10 \\
Tubificida & 1 & 5.26 & 3 & 13.30 \\
Unionoida & 1 & 2.63 & 1.82 \\
Veneroida & 38 & 100.00 & 165 & 1.21 \\
Total & 3.63 & 100.00 \\
\hline
\end{tabular}
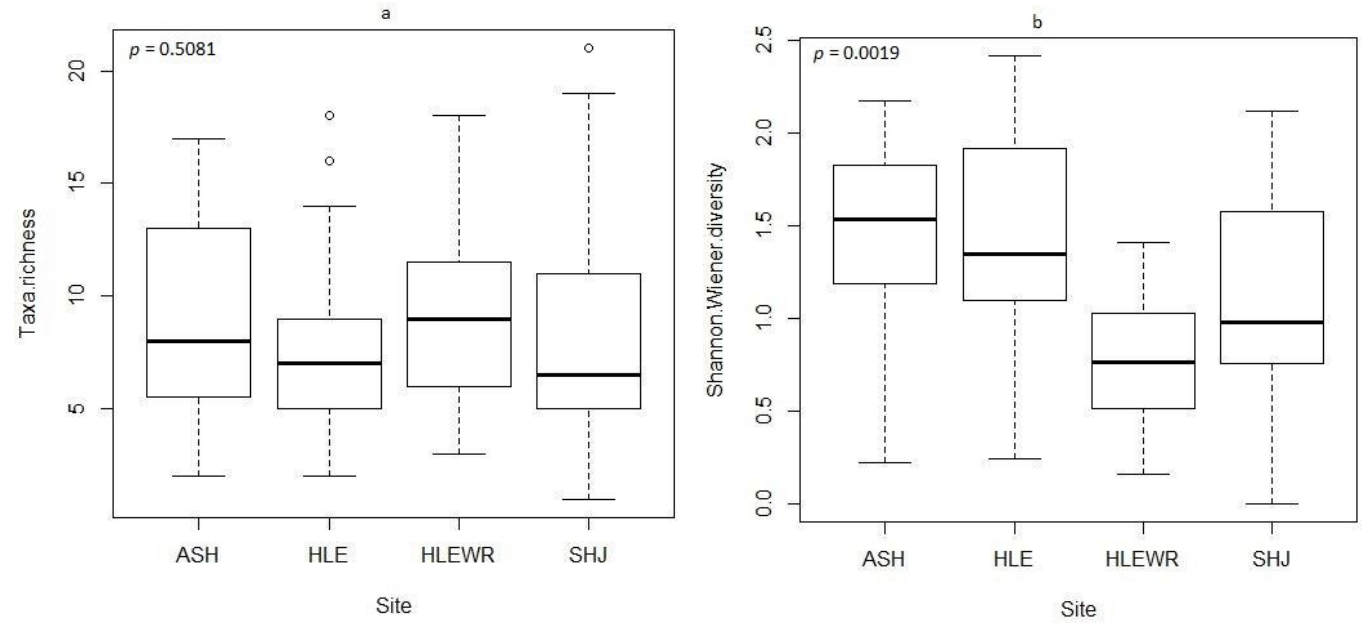

Figure 2. Comparison of mean values of macroinvertebrate taxa richness ( $a$ ) and ShannonWiener diversity (b) at sampling sites. ASH = Ashihe River upstream, $H L E=H u$-lan river downstream, HLEWR = Hu-lan estuary wetland reserve, SHJ = Songhua River along Harbin

Our results contracted with those of Šporka et al. (2006) in the stream of the Carpathian Mountains of central Europe; Wang et al. (2007) in Taihu lake watershed, Changzhou area; Zhao et al. (2012) in the bed sediment of the Yellow River; Pan et al. 
(2013) in the Upper Yellow and Yangtze Rivers; Zhang et al. (2014) in streams and rivers of lake Taihu Basin; Pham (2017) in Saigon river and its tributaries, Vietnam; Rosser and Pearson (2018) in tropical streams; Shabani et al. (2019) in the wetlands of the Sanjiang plain, who reported that aquatic insects were the most species-rich group and occurred in almost all of the sites. Their dominance may depend on the availability of allochthonous organic detritus from riparian structure (Vannote et al., 1980).

\section{Benthic macroinvertebrate functional feeding groups}

Figure $3 a, b, c$ report the percentage contributions of the various benthic macroinvertebrate FFGs at the sites during the three seasons. Gathering-collectors (GC) were the most dominant benthic macroinvertebrate FFG assemblages within all sites in spring and autumn. They also dominated the benthic communities in the HLEWR and SHJ in summer. Filtering-collectors (FC) and predators were the most abundant in the ASH and HLE, respectively in summer. It appeared that there's no significant difference in the total abundance of these six functional feeding groups among the sites during spring, summer and autumn (Kruskal-Wallis rank sum test, $p=0.677, p=0.681$, $p=0.302$, respectively). Pan et al. (2013) also found that gathering-collectors were the predominant macroinvertebrate FFGs in the source region of the Yangtze River. Fogelman et al. (2018) also reported that the gathering-collectors were the most dominant in the macroinvertebrate collection from the Susquehanna River, USA.

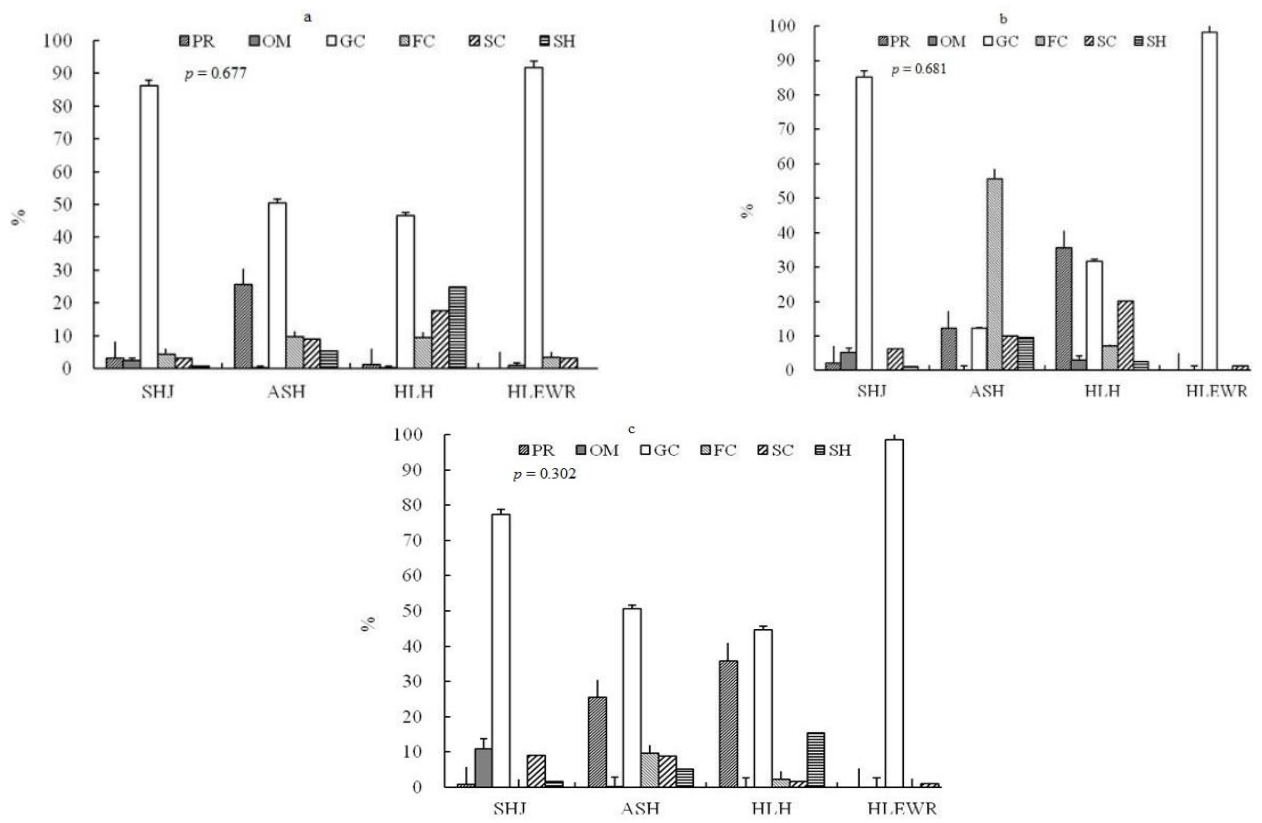

Figure 3. Percentages of macroinvertebrate FFGs in spring (a), summer (b) and autumn (c), $S H=$ shredders, $S C=$ scrapers, $F C=$ filtering-collectors, $G C=$ gathering-collectors, $P R=$ predators, $S H J=$ Songhua River along Harbin, $A S H=$ Ashihe River upstream, HLE $=H u$-lan river downstream, $H L E W R=H u$-lan estuary wetland reserve

\section{Relationships between physicochemical variables and benthic macroinvertebrates}

Figure 4 shows the CCA ordinations during the three seasons. During the spring period, the first two axes respectively explained 18.90 and $36.60 \%$ of benthic 
macroinvertebrate variances, with eigenvalues of 0.964 and 0.907 . Biotic data as Chironomus pallidivittatue, C. okinawanus, C. plumosus, Limnodrilus hoffmeisteri, Branchiura sowerbyi, Ephemera shengmi and Polypylis hemisphaerula exhibited high positive relationships with water temperature $(r=0.93)$ and $\operatorname{COD}_{\mathrm{Mn}}(r=0.94)$ at sites 1 , $2,3,21,23,25,26,27,28,29$ and 30 on the first axe. CCA indicated that Nippotipula spp., Ameletus spp., Iron spp., Heptagenia spp., Ephemera sachalinensis, Serratella spp., Ephemerella fusongensis, Leptophlebia spp., Paraleptophlebia spp., Corixa substriata, Hesperocorixa distanti, Gyraulus convexiuculus, Galba truncatula, Galba pervia, Radix auricularia, Valvata piscinalis, Stenopsyche marmorata, Hydropsyche nakaharai, Hydropsyche spp., Polycentropus spp. and Alloperla sapporoensis were positively correlated with TN and DO at sites 5, 7, 8, 10 and 11 on the second axis (Fig. 4a,b).

In summer season, the first two axes explained $55.40 \%$ of total variances, with eigenvalues of 0.915 and 0.958 , respectively. There were positive significant correlations of Tipulidae spp., Cryptochironomus defectus, Stictochironomus maculipennis, Chironomus okinawanus, Pentaneurella katterjokki, Glyptotendipes pallens, Ephemera shengmi, Unio douglasiae, Viviparus chui, Limnodrilus helveticus, Teneridrilus mastix, Limnodrilus hoffmeisteri with electronic conductivity $(r=0.78)$, depth $(r=0.69)$, water temperature $(r=0.94), \mathrm{TN}(r=0.71), \mathrm{NO}_{3}{ }^{-}-\mathrm{N}(r=0.87)$ and $\mathrm{pH}$ $(r=0.76)$ at sites $1,2,3,20,24,25,26,27,28,29$, and 30 on the first axis. While Tabanus spp., Nippotipula spp., Cricotopus sylvestris, Eukiefferiella gracei, Ameletus spp., Iron spp., Heptagenia spp., Baetis spp., Ephemerella spp., Nais spp., Limnodrilus claparedeianus, Alloperla sapporoensis, Alloperla nikkoensis, Alloperla spp., Haploperla spp., Stenophylax ondakesis, Stenophylax koizumii and Astenophylax grammicus were associated with DO and TP at sites 5, 6, 7, 8, 9 and 10 on the second axis (Fig. 4c,d).

During autumn, the first two CCA axes respectively explained 20.60 and $41.00 \%$ of total variances, with eigenvalues of 0.958 and 0.954 . Axis 1 showed positive correlations of water temperature, $\mathrm{TP}, \mathrm{TN}$, depth, $\mathrm{NH}_{3}-\mathrm{N}$, electronic conductivity, $\mathrm{COD}_{\mathrm{Mn}}$ and $\mathrm{NH}_{3}-\mathrm{N}$ on Unio douglasiae, Polypylis hemisphaerula, Viviparus chui, Galba pervia, Radix swinhoei, Cipangopaludina chinensis, Limnodrilus helveticus, Limnodrilus hoffmeisteri, Branchiura sowerbyi, Tubifex tubifex, Nais communis, Dero spp. While the second axis revealed that $\mathrm{pH}$ and DO were the most important variables to impact the distribution of Tabanus spp., Nippotipula spp., Holorusia spp., Procladius choreus, Stictochironomus akizukii, Ameletus spp., Iron spp., Heptagenia spp., Baetis spp., Baetis spp., Ephemera sachalinensis, Serratella spp., Ephemerella spp., Ephemerella fusongensis, Leptophlebia spp., Paraleptophlebia spp., Ephemera nigroptera, Corixa substriata, Hesperocorixa distanti, Sphaerium lacustre, Gyraulus convexiuculus, Radix auricularia, Radix ovata, Valvata piscinalis, Protohermes grandis, Parastenopsyche spp., Stenopsyche marmorata, Goera ramosa, Goera japonica, Goera kyotonis, Stenophylax ondakesis, Stenophylax koizumii, Astenophylax grammicus, Glyphotaelius admorsus, Hydropsyche nakaharai, Hydropsyche spp., Oecetis morii, Ganonema spp. and Polycentropus spp at sites 4, 5, 6, 7, 8, 9, 10, 11 and 12 (Fig. 4e,f).

Understanding the relative importance of environmental conditions is critical for understanding how to preserve generate benefits to aquatic macroinvertebrate communities (Wilkins et al., 2015). Our modeling demonstrated that benthic macroinvertebrate species richness values were strongly associated with physical and 
chemical conditions in the Hu-lan Estuary Natural Wetland Reserve and its surrounding waters. Environmental parameters as measured were very influential on macroinvertebrate diversity in freshwater habitats of this reserve. Moreover, several studies have demonstrated that differences in physical and chemical characteristics are detected anytime and with strong influence on aquatic community composition (Bertaso et al., 2015). Habitat quality was second important factor, implying that macroinvertebrate diversity also benefited from improved environmental conditions (Wilkins et al., 2015). Palmer et al. (1997), and Harper et al. (1998) argued that habitat heterogeneity can promote biotic recovery and biodiversity in aquatic environment and is often a goal of environment restoration.
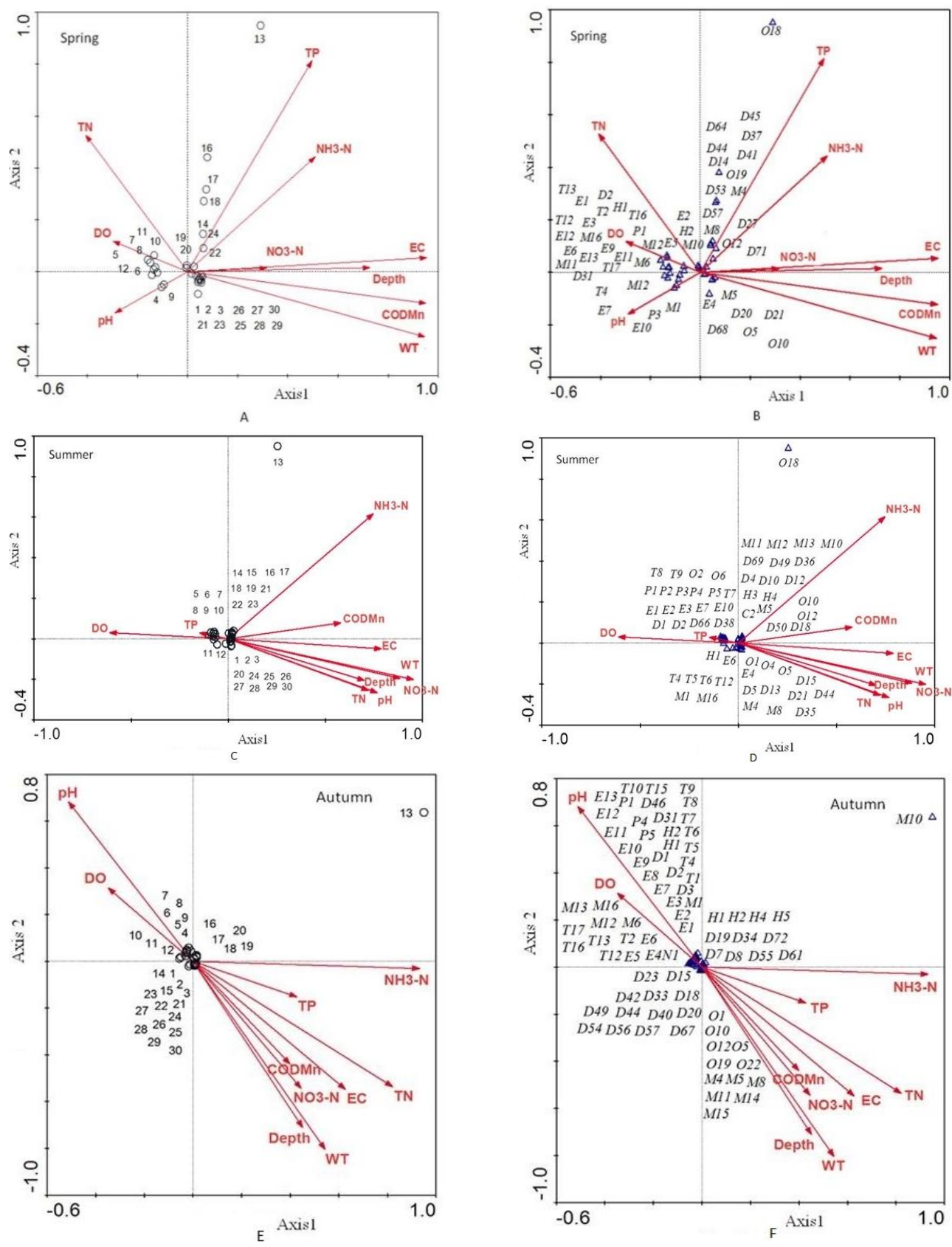

Figure 4. CCA plots relating the benthic macroinvertebrates associated with physicochemical variables in spring $(A, B)$, summer $(C, D)$ and autumn $(E, F)$ 
In our study, we recorded pollution-sensitive taxa, including Ephemeroptera, Plecoptera, Trichoptera and Odonata (EPTO) and benthic communities characterized by pollution-tolerant taxa, such as Diptera, Heterostropha, Hygrophila and Tubificida. Luo et al. (2017) also collected sensitive species (e.g., EPT taxa) and less diverse communities with dominance of tolerant species (e.g., Tubificids, Chironomids, and Physids) in the Liangjiang New Area. Although some taxa (e.g. EPTO) are sensitive to aquatic environment conditions (Barbour et al., 1992), many species in these orders are of conservation interest (Wilkins et al., 2015).

\section{Conclusion}

Our findings demonstrated the positive of benthic macroinvertebrate community compositions with environmental parameters. We found that Gathering-collectors were the most dominant benthic macroinvertebrate FFG assemblages, and recorded more sensitive and tolerant species in the Hu-lan Estuary Natural Wetland Reserve and its surrounding waters. In order to reach the conservation status assessment of species, we suggest that local faunas should be inventoried and described (many species remain unknown). Tolerance values for macroinvertebrates should be determined. More research teams using benthic macroinvertebrates to assess water quality should operate in this reserve. Wetland conservation efforts, such as planting aquatic vegetation in a watershed, can also help to improve water quality and restore natural flow regimes, and then may structure macroinvertebrate populations.

Acknowledgements. The financial support received from The Key Research and Development Program of China (Fund NO. 2016YFC0500406) for this research is gratefully acknowledged. We express also our gratitude to the staff of the Laboratory of Hydrobiology for the achievement of this work.

\section{REFERENCES}

[1] Allan, J. D. (2004): Landscapes and Riverscapes: The Influence of Land Use on Stream Ecosystems. - Annu. Rev. Ecol. Syst. 35: 257-284.

[2] Barbour, M. T., Graves, C. G., Plafkin, J. L., Wisseman, R. W., Bradley, B. P. (1992): Evaluation of EPA's Rapid Bioassessment Benthic Metrics: Metric Redundancy and Variability among Reference Stream Sites. - Environ Toxicol Chem. 11: 437-449.

[3] Barbour, M. T., Gerritsen, J., Snyder, B. D., Stribling, J. B. (1999): Rapid Bioassessment Protocols for Use in Streams and Wadeable Rivers. - In: Periphyton, Benthic Macroinvertebrates and Fish. ed. In US Environmental Protection Agency (USEPA). Washington DC: Office of Water, USEPA.

[4] Bertaso, T. R. N., Spies, M. R., Kotzian, C. B., Flores, M. L. T. (2015): Effects of forest conversion on the assemblages' structure of aquatic insects in subtropical regions. Revista Brasileira de Entomologia 59: 43-49.

[5] Cao, Y., Bark, A. W., Williams, W. P. (1997): Analysing Benthic Macroinvertebrate Community Changes along a Pollution Gradient: A Framework for the Development of Biotic Indices. - Wat. Res. 31(4): 884-92.

[6] Cummins, K. W. (1973): Trophic Relations of Aquatic Insects. - Annual Review of Entomology 18: 183-206.

[7] Cummins, K. W. (1974): Structure and Function of Stream Ecosystems. - Bio Science 24(11): 631-641. 
[8] Cummins, K. W., Klug, M. J. (1979): Feeding Ecology of Stream Invertebrates. - Annual Review of Ecology and Systematics 10: 147-72.

[9] Cummins, K. W. (1992): Invertebrates. - In: Calow, G. E., Petts, P. (eds.) The Rivers Handbook: Hydrological and Ecological Principles. Blackwell Scientific, London, UK, Pages 234-250.

[10] Dudgeon, D. (1999): Tropical Asian Streams: Zoobenthos, Ecology and Conservation. Hong Kong Universty Press.

[11] Fogelman, K. J., Bilger, M. D., Holt, J. R., Matlaga, D. P. (2018): Decomposition and Benthic Macroinvertebrate Communities of Exotic Japanese Knotweed (Fallopia japonica) and American Sycamore (Platanus occidentalus) Detritus within the Susquehanna River. - Journal of Freshwater Ecology 33(1): 299-310.

[12] Fu, L., Jiang, Y., Ding, J., Liu, Q., Peng, Q. Z., Kang, M. Y. (2016): Impacts of Land Use and Environmental Factors on Macroinvertebrate Functional Feeding Groups in the Dongjiang River Basin, Southeast China. - Journal of Freshwater Ecology 31(1): 21-35.

[13] Hammer, O., Harper, D., Ryan, P. (2001): PAST: Paleontological Statistics Software Package for Education and Data Analysis. - Palaeontol Electronica 4: 1-9.

[14] Hammer, O., Ryan, P. (2008): PAST. - Paleontological Statistics, Ver. 1. 77.

[15] Harper, D., Ebrahimnexhad, M., Climent, I., Cot, F. (1998): Artificial Rifles in River Rehabilitation: Setting the Goals and Measuring the Successes. - Aquat Conserv Mar Freshwat Ecosyst 8: 5-16.

[16] Hilsenhoff, W. L. (1977): Use of Arthropods to Evaluate Water Quality of Streams. Technical Bulletin No. 100, Department of Natural Resources, Madison.

[17] Lenat, D. R. (1987): The Macroinvertebrate Fauna of the Little River, North Carolina: Taxa List and Seasonal Trends. - Arch. Hydrobiol. 110(1): 19-43.

[18] Lenat, D. R. (1994): Using Aquatic Insect to Monitor Water Quality. - In: Lixin, T., Morse, J. C., Liantang, Y. (eds.) Aquatic Insects of China Useful for Monitoring Water Quality. Hohai Uniyersity Press, Nanjing, People's Republic of China.

[19] Lenat, D. R., Penrose, D. L. (1996): History of the EPT Taxa Richness Metric. - Bulletin North American Benthological Society 13: 305-7.

[20] Liu, M. H. (2012): The Ecological Monitoring and Health Assessment of Aquatic Animals Community in Hulan Estuary Natural Reserves. - Northeast Forestry University.

[21] Luo, K., Hu, X., He, Q., Wu, Z., Cheng, H., Hu, Z., Mazumder, A. (2017): Impacts of Rapid Urbanization on the Water Quality and Macroinvertebrate Communities of Streams: A Case Study in Liangjiang New Area, China. - Science of the Total Environment 621: 1601-1614.

[22] Maloney, K., Feminella, J. (2006): Evaluation of Single- and Multi-Metric Benthic Macroinvertebrate Indicators of Catchment Disturbance over Time at the Fort Benning Military Installation, Georgia, USA. - Ecological Indicators 6(3): 469-484.

[23] Masese, F. O., Nzula, K., Kipkembo, J., Gettel, G. M., Irvine, K., McClain, M. E. (2014): Macroinvertebrate Functional Feeding Groups in Kenyan Highland Streams: Evidence for a Diverse Shredder Guild. - Freshwater Science 33(2): 435-450.

[24] Merritt, R. W., Cummins, K. W., Berg, M. B. (1996): An Introduction to the Aquatic Insects of North America. Third Edit. - Kendall/Hunt Publishing Company, Dubuque, USA.

[25] Merritt, R. W., Cummins, K. W., Berg, M. B., Novak, J. A., Higgins, M. J., Wessell, K. J., Lessard, J. L. (2002): Development and Application of a Macroinvertebrate Functional-Group Approach to the Bioassessment of Remnant River Oxbows in Southwest Florida. - Journal of the North American Benthological Society 21(2): 290310.

[26] Merritt, R. W., Cummins, K. W., Berg, M. B. (2008): An Introduction to the Aquatic Insects of North America. 4th ed. - Iowa, USA: Kendall/Hunt Publishing Company.

[27] Morse, J., Yang, L., Tian, L. (1994): Aquatic Insects of China Useful for Monitoring Water Quality. - Hohai University Press, Nanjing, People's Republic of China. 
[28] Morse, J. C., Bae, Y. J., Munkhjargal, G., Sangpradub, N., Tanida, K., Vshivkova, T. S., Wang, B., Yang, L., Yule, C. M. (2007): Freshwater Biomonitoring with Macroinvertebrates in East Asia. - Front Ecol Environ 52(1): 33-4.

[29] Ortiz, J. D., Puig, M. A. (2007): Point Source Effects on Density, Biomass and Diversity of Benthic Macroinvertebrates in a Mediterranean Stream. - River Research and Applications: 170(2): 155-70.

[30] Palmer, M. A., Hakenkamp, C. C., Nelson-Baker, K. (1997): Ecological Heterogeneity in Streams: Why Variance Matters. - Journal of the North American Benthological Society 16(1): 189-202.

[31] Pan, B., Wang, Z., Li, Z., Yu, G., Xu, M., Zhao, N., Brierley, G. (2013): An Exploratory Analysis of Benthic Macroinvertebrates as Indicators of the Ecological Status of the Upper Yellow and Yangtze Rivers. - Journal of Geographical Sciences 23(5): 871-882.

[32] Pham, A. D. (2017): Linking Benthic Macroinvertebrates and Physicochemical Variables for Water Quality Assessment in Saigon River and Its Tributaries, Vietnam. - IOP Conf. Series: Earth and Environmental Science 92: 012053.

[33] Plafkin, J. L., Barbour, M. T., Porter, K. D., Gross, S. K., Hughes, R. M. (1989): Rapid Bioassessment Protocols for Use in Streams and Rivers: Benthic Macroinvertebrates and Fish. - USEPA, EPA/44/4-89-001.

[34] Rivera-Usme, J., Pinilla, G., Rangel-Churio, J., Castro, M., Camacho-Pinzón, D. (2015): Biomass of Macroinvertebrates and Physicochemical Characteristics of Water in an Andean Urban Wetland of Colombia. - Brazilian Journal of Biology 75(1): 180-190.

[35] Rosser, Z. C., Pearson, R. G. (2018): Hydrology, Hydraulics and Scale Influence Macroinvertebrate Responses to Disturbance in Tropical Streams Responses to Disturbance in Tropical Streams. - Journal of Freshwater Ecology 33(1): 1-17.

[36] Shabani, I. E., Liu, M. H., Yu, H. X., Muhigwa, J.-B. B., Geng, F. F. (2019): Benthic Macroinvertebrate Diversity and Functional Feeding Groups in Relation to Physicochemical Factors in Sanjiang Plain Wetlands, Northeast China. - Applied Ecology and Environmental Research 17(2): 3387-3402.

[37] Šporka, F., Vlek, H. E., Bulánková, E., Krno, I. (2006): Influence of Seasonal Variation on Bioassessment of Streams Using Macroinvertebrates. - Hydrobiologia 566(1): 543555.

[38] Swaminathan, M. S. M. (2003): Bio-Diversity: An Effective Safety Net against Environmental Pollution. - Environmental Pollution 126(3): 287-291.

[39] Tan, K. W., Beh, W. C. (2016): Evaluation of Water Quality and Benthic Macrointervebrates Fauna Relationship Using Principal Component Analysis (PCA): A Case Study of Cameron Highlands Malaysia. - Environmental Management and Sustainable Development 5(1): 187-208.

[40] Thorp, J. H., Covich, A. P. (1991): Ecology and Classification of North American Freshwater Invertebrates. - Academic Press.

[41] Tong, Y. (1996): Annelida, Hirudinae. Fauna Sinica. Natural Science Foundation of China in the Period of the Eighth Five-Year Plan. - Science Press, Beijing.

[42] Vannote, R. L., Minshall, G. W., Cummins, K. W., Sedell, J. R., Cushing, C. E. (1980): The River Continuum Concept. - Canadian Journal of Fisheries and Aquatic Sciences 37(1): 130-137.

[43] Wang, B., Xu, D., Yang, L., Shen, L., Yu, H. (2007): Characteristics of Benthic Macroinvertebrates Communities in Relation to Environment in Upper Reaches of the Taihu Lake Watershed in Changzhou Area. - J Ecol Rural Environ. 23: 47-51.

[44] Wilkins, P. M., Cao, Y., Heske, E. J., Levengood, J. M. (2015): Influence of a Forest Preserve on Aquatic Macroinvertebrates, Habitat Quality, and Water Quality in an Urban Stream. - Urban Ecosyst. 18: 989-1006.

[45] Zhang, Y., Liu, L., Cheng, L., Cai, Y., Yin, H., Gao, J., Gao, Y. (2014): Macroinvertebrate Assemblages in Streams and Rivers of a Highly Developed Region (Lake Taihu Basin, China). - Aquatic Biology 23: 15-28. 


$$
-11785 \text { - }
$$

[46] Zhao, W., Wang, H., Hongzhu, W., Close, P. G. (2012): Macroinvertebrates in the Bed Sediment of the Yellow River. - International Journal of Sediment Research 26(3): 25568.

\section{APPENDIX}

Appendix 1. Benthic macroinvertebrate taxa list in the Hu-lan Estuary Natural Wetland Reserve and its surrounding waters. FFG = functional feeding groups, ASH = Ashihe River upstream, SHJ = Songhua River along Harbin, HLE = Hu-lan river downstream, HLEWR = $H u$-lan estuary wetland reserve, $S H=$ shredders, $S C=$ scrapers, $F C=$ filtering-collectors, $G C=$ gathering-collectors, $P R=$ predators

\begin{tabular}{|c|c|c|c|c|c|c|}
\hline $\begin{array}{c}\text { Taxon } \\
\end{array}$ & Code & FFG & $\overline{\text { ASH }}$ & HLE & HLEWR & SHJ \\
\hline \multicolumn{7}{|l|}{ ARHYNCHOBDELLIDA } \\
\hline Whitmania spp. & H3 & PR & 1 & & & 1 \\
\hline Erpobdella octoculata & H5 & PR & & & & \\
\hline \multicolumn{7}{|l|}{ COLEOPTERA } \\
\hline Chlaenius spp. & $\mathrm{C} 1$ & PR & 1 & & & \\
\hline Sialis rotunda & $\mathrm{C} 2$ & PR & 1 & 1 & & \\
\hline \multicolumn{7}{|l|}{ DECAPODA } \\
\hline Leander modestus & N3 & $\mathrm{OM}$ & & 1 & & \\
\hline Palaemon sinensis & N4 & $\mathrm{OM}$ & & 1 & 1 & 1 \\
\hline \multicolumn{7}{|l|}{ DIPTERA } \\
\hline Tabanus spp. & D1 & PR & 1 & 1 & & \\
\hline Nippotipula spp. & D2 & $\mathrm{SH}$ & 1 & 1 & & \\
\hline Holorusia spp. & D3 & $\mathrm{SH}$ & 1 & & & \\
\hline Antocha spp. & D4 & $\mathrm{GC}$ & 1 & 1 & & \\
\hline Tipulidae spp. & D5 & $\mathrm{SH}$ & & 1 & & 1 \\
\hline Pilaria spp. & D6 & PR & 1 & & & \\
\hline Cryptochironomus digitatus & D7 & PR & & & & 1 \\
\hline Limonia spp. & D8 & $\mathrm{SH}$ & 1 & & & \\
\hline Chaoborus spp. & D10 & PR & 1 & 1 & & \\
\hline Chironomus lugubris & D11 & GC & & & & 1 \\
\hline Harnischia fuscimana & D12 & GC & & 1 & & 1 \\
\hline Cryptochironomus defectus & D13 & PR & & 1 & & 1 \\
\hline Polypedilum albicorne & D14 & SH & & 1 & & \\
\hline Stictochironomus maculipennis & D15 & $\mathrm{OM}$ & & & & 1 \\
\hline Tanypus punctipennis & D16 & $\mathrm{OM}$ & & & 1 & \\
\hline Stictochironomus spp. & D17 & $\mathrm{OM}$ & & & & 1 \\
\hline Chironomus dorsalis & D18 & GC & & 1 & 1 & 1 \\
\hline Polypedilum pedestre & D19 & SH & & 1 & & \\
\hline Chironomus pallidivittatue & D20 & GC & & 1 & 1 & 1 \\
\hline Chironomus okinawanus & D21 & GC & & 1 & 1 & 1 \\
\hline Dicrotendipes pelochloris & D23 & GC & & & 1 & \\
\hline Polypedilum cultellatum & $\mathrm{D} 24$ & $\mathrm{SH}$ & & & & 1 \\
\hline Glyptotendipes tokunagai & D25 & FC & & & 1 & 1 \\
\hline Glyptotendipes gripekoveni & D26 & $\mathrm{FC}$ & & & 1 & \\
\hline Cladotanytarsus vanderwulpi & $\mathrm{D} 27$ & GC & & 1 & & \\
\hline Acricotopus lucens & D28 & GC & & & & 1 \\
\hline Cryptochironomus fulvus & D29 & PR & & & & 1 \\
\hline Smittia aterrima & D30 & GC & 1 & 1 & 1 & \\
\hline Procladius choreus & D31 & PR & 1 & & 1 & \\
\hline Polypedilum flavum & D32 & SH & & 1 & & \\
\hline Chironomus flaviplumus & D33 & GC & & 1 & & 1 \\
\hline Tanytarsus mendex & D34 & FC & & 1 & & \\
\hline Pentaneurella katterjokki & D35 & - & 1 & & & 1 \\
\hline Cricotopus sylvestris & D36 & $\overline{\mathrm{SH}}$ & & 1 & 1 & 1 \\
\hline
\end{tabular}




\begin{tabular}{|c|c|c|c|c|c|c|}
\hline Taxon & Code & FFG & $\overline{\text { ASH }}$ & HLE & HLEWR & SHJ \\
\hline Hydrobaenus lugubris & D37 & $\mathrm{SC}$ & & 1 & & \\
\hline Cricotopus annulator & D38 & $\mathrm{SH}$ & 1 & & & \\
\hline Tanypus villipennis & D39 & PR & & 1 & & \\
\hline Chironomus anthracinus & D40 & GC & & & 1 & 1 \\
\hline Polypedilum sordens & D41 & $\mathrm{SH}$ & & 1 & & \\
\hline Demicryptochironomus spp. & D42 & GC & & 1 & & \\
\hline Procladius spp. & D43 & PR & & & & 1 \\
\hline Glyptotendipes pallens & D44 & $\mathrm{FC}$ & & 1 & 1 & 1 \\
\hline Polypedilum asakawanense & D45 & $\mathrm{SH}$ & & 1 & & \\
\hline Stictochironomus akizukii & D46 & $\mathrm{OM}$ & 1 & & 1 & \\
\hline Demicryptochironomus vulneratus & D47 & GC & & 1 & & \\
\hline Chironomus circumdatus & D48 & GC & & 1 & 1 & \\
\hline Lipiniella sekunada & D49 & GC & & 1 & 1 & \\
\hline Cricotopus trifasciatus & D50 & $\mathrm{SH}$ & & 1 & & \\
\hline Dicrotendipes tritomus & D51 & GC & & 1 & & \\
\hline Endochironomus tendens & D52 & $\mathrm{SH}$ & & 1 & & \\
\hline Diplocladius spp. & D53 & GC & & 1 & & 1 \\
\hline Hexatoma bicolor & D54 & PR & & 1 & & \\
\hline Dicrotendipes tamaviridis & D55 & GC & & 1 & & \\
\hline Polypedilum scalaenum & D56 & $\mathrm{SH}$ & & & 1 & 1 \\
\hline Orthocladius thienemanni & D57 & GC & & 1 & & 1 \\
\hline Orthocladius vaillanti & D58 & GC & & 1 & & \\
\hline Cryptotendipes spp. & D59 & GC & & & & 1 \\
\hline Parachironomus arcuatus & D60 & PR & & 1 & & \\
\hline Cryptochironomus ussouriensis & D61 & PR & & 1 & 1 & \\
\hline Chironomus riparius & D62 & $\mathrm{OM}$ & & & & 1 \\
\hline Chironomus salinarius & D63 & $\mathrm{OM}$ & & & 1 & \\
\hline Polypedilum surugense & D64 & SH & & 1 & & 1 \\
\hline Chironomus attenuatus & D65 & $\mathrm{OM}$ & & & 1 & \\
\hline Eukiefferiella gracei & D66 & GC & 1 & & & \\
\hline Polypedilum nubeculosum & D67 & $\mathrm{SH}$ & & 1 & 1 & 1 \\
\hline Chironomus plumosus & D68 & $\mathrm{OM}$ & & & & 1 \\
\hline Macropelopia nebulosa & D69 & PR & & 1 & 1 & 1 \\
\hline Paracladopelma undine & D70 & GC & 1 & & & \\
\hline Acricotopus longipalpus & D71 & GC & & 1 & & \\
\hline EPHEMEROPTERA & & & & & & \\
\hline Ameletus spp. & E1 & GC & 1 & 1 & & \\
\hline Iron spp. & E2 & $\mathrm{FC}$ & 1 & 1 & 1 & \\
\hline Heptagenia spp. & E3 & $\mathrm{SC}$ & 1 & & & \\
\hline Ephemera shengmi & E4 & GC & 1 & 1 & 1 & 1 \\
\hline Ephemera nigroptera & E5 & GC & 1 & & & \\
\hline Ephemera sachalinensis & E6 & GC & 1 & & & 1 \\
\hline Baetis spp. & E7 & GC & 1 & & & \\
\hline Baetiell spp. & E8 & GC & 1 & & & \\
\hline Serratella spp. & E9 & GC & 1 & & & \\
\hline Ephemerella spp. & E10 & GC & 1 & & & \\
\hline Ephemerella fusongensis & E11 & GC & 1 & & & \\
\hline Leptophlebia spp. & E12 & GC & 1 & & & \\
\hline $\begin{array}{l}\text { Paraleptophlebia spp. } \\
\text { HETEROPTERA }\end{array}$ & E13 & GC & 1 & & & \\
\hline Corixa substriata & $\mathrm{H} 1$ & PR & 1 & 1 & & \\
\hline Hesperocorixa distanti & $\mathrm{H} 2$ & PR & & 1 & & \\
\hline Hesperocorixa kirkaldy & $\mathrm{H} 3$ & PR & & 1 & & \\
\hline Sigra distanti & $\mathrm{H} 4$ & PR & & 1 & & \\
\hline Ranatra chinensis & H5 & PR & 1 & & & \\
\hline Hesperocorixa valgaris & H6 & PR & & 1 & & \\
\hline HETEROSTROPHA & & & & & & \\
\hline Cipangopaludina chinensis & M15 & $\mathrm{SC}$ & & & 1 & \\
\hline
\end{tabular}




$$
-11787 \text { - }
$$

\begin{tabular}{|c|c|c|c|c|c|c|}
\hline Taxon & Code & FFG & $\overline{\text { ASH }}$ & HLE & HLEWR & SHJ \\
\hline $\begin{array}{l}\text { Valvata piscinalis } \\
\text { HYGROPHILA }\end{array}$ & M16 & $\mathrm{SC}$ & 1 & & 1 & 1 \\
\hline Polypylis hemisphaerula & M5 & $\mathrm{SC}$ & & 1 & 1 & \\
\hline Gyraulus convexiuculus & M6 & SC & 1 & & 1 & \\
\hline Hippeutis cantori & M7 & $\mathrm{SC}$ & & 1 & & \\
\hline Viviparus chui & M8 & $\mathrm{SC}$ & & 1 & 1 & 1 \\
\hline Semisulcospira amurensis & M9 & SC & 1 & & 1 & 1 \\
\hline Galba truncatula & M10 & $\mathrm{SC}$ & & 1 & & 1 \\
\hline Galba pervia & M11 & SC & & 1 & 1 & 1 \\
\hline Radix auricularia & M12 & SC & 1 & 1 & 1 & 1 \\
\hline Radix ovata & M13 & $\mathrm{SC}$ & 1 & 1 & 1 & 1 \\
\hline Radix swinhoei & M14 & SC & 1 & 1 & 1 & \\
\hline $\begin{array}{l}\text { NEUROPTERA } \\
\text { Protohermes grandis } \\
\text { ODONATA }\end{array}$ & $\mathrm{N} 1$ & PR & & 1 & & \\
\hline Ictinogomphus spp. & Od1 & PR & & 1 & & 1 \\
\hline $\begin{array}{l}\text { Macromidae spp. } \\
\text { PLECOPTERA }\end{array}$ & Od2 & PR & 1 & & & \\
\hline Alloperla sapporoensis & $\mathrm{P} 1$ & PR & 1 & 1 & & \\
\hline Alloperla nikkoensis & $\mathrm{P} 2$ & PR & 1 & & & \\
\hline Alloperla spp. & P3 & PR & 1 & & & \\
\hline Haploperla spp. & P5 & PR & 1 & & & \\
\hline Cyamia spp. & P6 & PR & 1 & & & \\
\hline Doddsia iaponica & $\mathrm{P} 7$ & $\mathrm{SH}$ & 1 & & & \\
\hline RHYNCHOBDELLIDA & & & & & & \\
\hline Parabdella quadrioculata & $\mathrm{H} 1$ & PR & 1 & & & \\
\hline Glossiphonia lata & $\mathrm{H} 2$ & PR & 1 & 1 & & 1 \\
\hline $\begin{array}{l}\text { Helobdella stagnalis } \\
\text { TRICHOPTERA }\end{array}$ & $\mathrm{H} 4$ & PR & & 1 & & \\
\hline Parastenopsyche spp. & $\mathrm{T} 1$ & GC & 1 & & & \\
\hline Stenopsyche marmorata & $\mathrm{T} 2$ & PR & 1 & & & \\
\hline Parastenopsyche sauteri & $\mathrm{T} 3$ & $\mathrm{GC}$ & 1 & & & \\
\hline Goera ramosa & $\mathrm{T} 4$ & SC & 1 & & & \\
\hline Goera japonica & $\mathrm{T} 5$ & $\mathrm{SC}$ & 1 & & & \\
\hline Goera kyotonis & $\mathrm{T} 6$ & $\mathrm{SC}$ & 1 & & & \\
\hline Stenophylax ondakesis & $\mathrm{T} 7$ & $\mathrm{SH}$ & 1 & & & \\
\hline Stenophylax koizumii & $\mathrm{T} 8$ & $\mathrm{SH}$ & 1 & & & \\
\hline Astenophylax grammicus & $\mathrm{T} 9$ & $\mathrm{SH}$ & 1 & & & \\
\hline Glyphotaelius spp. & $\mathrm{T} 10$ & $\mathrm{SH}$ & 1 & & & \\
\hline Apatania spp. & $\mathrm{T} 11$ & $\mathrm{SC}$ & 1 & & & \\
\hline Hydropsyche nakaharai & $\mathrm{T} 12$ & $\mathrm{FC}$ & 1 & 1 & & \\
\hline Hydropsyche spp. & $\mathrm{T} 13$ & $\mathrm{FC}$ & 1 & & & \\
\hline Ptllocolepus spp. & $\mathrm{T} 14$ & GC & 1 & & & \\
\hline Oecetis morii & $\mathrm{T} 15$ & $\mathrm{GC}$ & 1 & & & \\
\hline Ganonema spp. & $\mathrm{T} 16$ & SH & 1 & & & \\
\hline Polycentropus spp. & $\mathrm{T} 17$ & $\mathrm{FC}$ & 1 & & & \\
\hline Hydroptila spp. & $\mathrm{T} 18$ & $\mathrm{SC}$ & 1 & & & \\
\hline Goera spp. & $\mathrm{T} 19$ & $\mathrm{SC}$ & 1 & & & \\
\hline $\begin{array}{l}\text { Astenophylax spp. } \\
\text { TUBIFICIDA }\end{array}$ & $\mathrm{T} 20$ & $\mathrm{SH}$ & 1 & & & \\
\hline Limnodrilus helveticus & O1 & GC & & 1 & & 1 \\
\hline Nais spp. & $\mathrm{O} 2$ & GC & & & 1 & 1 \\
\hline Limnodrilus udekemianus & O3 & GC & & 1 & 1 & 1 \\
\hline Teneridrilus mastix & $\mathrm{O} 4$ & GC & & & & 1 \\
\hline Limnodrilus hoffmeisteri & O5 & GC & 1 & 1 & 1 & 1 \\
\hline Limnodrilus claparedeianus & O6 & GC & 1 & & & \\
\hline Spirosperma nikolskyi & $\mathrm{O} 7$ & GC & & & & 1 \\
\hline Aulodrilus pigueti & O8 & $\mathrm{GC}$ & & 1 & 1 & \\
\hline
\end{tabular}




$$
-11788-
$$

\begin{tabular}{|c|c|c|c|c|c|c|}
\hline Taxon & Code & FFG & $\overline{\mathrm{ASH}}$ & HLE & HLEWR & SHJ \\
\hline Aulodrilus japonicus & O9 & GC & & 1 & 1 & \\
\hline Branchiura sowerbyi & $\mathrm{O} 10$ & GC & & 1 & 1 & 1 \\
\hline Chaetogaster diaphanus & $\mathrm{O} 11$ & GC & & 1 & 1 & 1 \\
\hline Tubifex tubifex & $\mathrm{O} 12$ & GC & & 1 & 1 & 1 \\
\hline Nais bretscheri & $\mathrm{O} 13$ & GC & & & 1 & 1 \\
\hline Nais pseudobtusa & $\mathrm{O} 14$ & GC & & & & 1 \\
\hline Paranais frici & $\mathrm{O} 15$ & GC & & & 1 & 1 \\
\hline Pristinella acuminata & O16 & GC & & & 1 & \\
\hline Nais simplex & $\mathrm{O} 17$ & GC & & & 1 & \\
\hline Slavina spp. & $\mathrm{O} 18$ & GC & & & 1 & 1 \\
\hline Nais communis & O19 & GC & & 1 & 1 & 1 \\
\hline Uncinais uncinata & $\mathrm{O} 20$ & GC & & 1 & & \\
\hline Dero spp. & $\mathrm{O} 22$ & GC & & & 1 & \\
\hline Dero digitata & $\mathrm{O} 23$ & GC & & & & 1 \\
\hline UNIONOIDA & & & & & & \\
\hline Corbicula nittens & M2 & $\mathrm{FC}$ & & & 1 & \\
\hline Lanceolaria grayana & M3 & $\mathrm{FC}$ & & & & 1 \\
\hline $\begin{array}{l}\text { Unio douglasiae } \\
\text { VENEROIDA }\end{array}$ & M4 & FC & & 1 & 1 & 1 \\
\hline Sphaerium lacustre & M1 & $\mathrm{FC}$ & 1 & & & \\
\hline Sphaerium spp. & $\mathrm{N} 2$ & $\mathrm{FC}$ & 1 & 1 & 1 & \\
\hline Total & & & 71 & 78 & 52 & 59 \\
\hline
\end{tabular}

\footnotetext{
$1=$ present
} 